Abstracta Iranica Abstracta Iranica

Revue bibliographique pour le domaine irano-aryen

Volume 42-43 | 2021

Comptes rendus des publications de 2019-2020

\title{
Michal Biran, Jonathan Brack, Francesca Fiaschetti (eds.). Along the Silk Roads in Mongol Eurasia: Generals, Merchants and Intellectuals
}

\section{Simon Berger}

\section{OpenEdition}

1 Journals

\section{Édition électronique}

URL : https://journals.openedition.org/abstractairanica/53772

DOI : 10.4000/abstractairanica. 53772

ISSN : 1961-960X

Éditeur :

CNRS (UMR 7528 Mondes iraniens et indiens), Éditions de l'IFRI

Référence électronique

Simon Berger, « Michal Biran, Jonathan Brack, Francesca Fiaschetti (eds.). Along the Silk Roads in Mongol Eurasia: Generals, Merchants and Intellectuals », Abstracta Iranica [En ligne], Volume 42-43 | 2021, document 27, mis en ligne le 30 décembre 2021, consulté le 14 décembre 2022. URL : http:// journals.openedition.org/abstractairanica/53772; DOI : https://doi.org/10.4000/abstractairanica. 53772

Ce document a été généré automatiquement le 14 décembre 2022.

Tous droits réservés 


\title{
Michal Biran, Jonathan Brack, Francesca Fiaschetti (eds.). Along the Silk Roads in Mongol Eurasia: Generals, Merchants and Intellectuals
}

\author{
Simon Berger
}

\section{RÉFÉRENCE}

Michal Biran, Jonathan Brack, Francesca Fiaschetti (eds.). Along the Silk Roads in Mongol Eurasia: Generals, Merchants and Intellectuals. Oakland: University of California Press, 2020, I-XV, 335 p., 13 maps, 20 halftones, 2 tables, ISBN: 9780520298750

1 Cet ouvrage collectif constitue la seconde publication, après le dossier In the Service of the Khan: Elites in Transition in Mongol Eurasia publié sous la direction de Michal Biran dans Asiatische Studien - Études Asiatiques en 2017, issue du projet ERC « Mobility, Empire and Cross Cultural Contacts in Mongol Eurasia» de l'Université Hébraïque de Jérusalem, qui avait permis de rassembler un très grand nombre de données sur différentes figures, connues et moins connues, de l'Empire mongol à travers des sources très diverses, dont les résultats bruts n'ont malheureusement pas encore été rendus publics. Comme l'annonce le titre, le fil conducteur des différentes contributions est le concept, quelque peu galvaudé, de "Routes de la Soie », ici pris dans le sens vague de toute forme d'échange non seulement commercial, mais encore intellectuel, technologique, humain... à l'échelle de l'Eurasie et facilitée par le caractère transcontinental de la domination mongole. Adoptant une perspective exclusivement biographique, chacun des articles regroupés dans ce volume s'attache à retracer le parcours d'un acteur de ces échanges. Les individus étudiés sont classés en trois catégories, qui forment les trois parties de l'ouvrage :

2 1) Les généraux (Generals) 

compte rendu dans ce même numéro d'AbstIr)

4 - S. N. Ylldız, «Baiju: The Mongol Conqueror at the Crossfire of Dynatic Struggle »; (cf. le compte rendu dans ce même numéro d'AbstIr)

5 - M. Biran, "Qutulun: The Warrior Princess of Mongol Central Asia »; (cf. le compte rendu dans ce même numéro d'AbstIr)

6 - M. Mukai et F. Fiaschetti, « Yang Tingbi: Mongol Expansion along the Maritime Silk Roads ";

7 - A. Mazor, « Sayf al-Dīn Qipchaq al-Manșūrī: Defection and Ethnicity between Mongols and Mamluks »; (cf. le compte rendu dans ce même numéro d' AbstIr)

8 - V. Shurany, «Tuqtuqa and his Descendants: Cross-Regional Mobility and Political Intrigue in the Mongol Yuan Army ";

12 - M. Gill, «Jamāl al-Dīn al-Ṭībī: The Iraqi Trader Who Traversed Asia »; (cf. le compte rendu dans ce même numéro d' AbstIr)

13 - S. Kovács, « Taydula: A Golden Horde Queen and Patron of Christian Merchants »;

14 3) Les intellectuels (Intellectuals)

15 - J. Brack, « Rashīd al-Dīn: Buddhism in Iran and the Mongol Silk Roads »; (cf. le compte rendu dans ce même numéro d' AbstIr)

16 - Y. Isahaya, «Fu Mengzhi: "The Sage of Cathay" in Mongol Iran and Astral Sciences along the Silk Roads "; (cf. le compte rendu dans ce même numéro d' AbstIr)

17 - H. Kim, « 'Īsa Kelemechi: A Translator Turned Envoy between Asia and Europe »; (cf. le compte rendu dans ce même numéro d' AbstIr)

18 - B. De Nicola, «Pādshāh Khatun: An Example of Architectural, Religious, and Literary Patronage in Ilkhanid Iran »; (cf. le compte rendu dans ce même numéro d' AbstIr)

19 - O. Amir, «Islamic Learning on the Silk Roads: The Career of Jalāl al-Dīn al-Akhawī ». (cf. le compte rendu dans ce même numéro d' AbstIr)

20 L'ensemble est suivi par un glossaire, une chronologie indicative et un index général. Hormis ceux ne concernant pas les mondes iraniens, ces articles sont recensés dans ce volume.

\section{AUTEURS}

\section{SIMON BERGER}

Doctorant EHESS, CETOBAC, Paris 